\title{
Evaluation of serotonin receptors (5HTR2A and 5HTR3A) mRNA expression changes in tumor of breast cancer patients
}

\author{
Zahra Olfati ${ }^{1}$, Garshasb Rigi*2, 3 (D) Hajar Vaseghi $^{4}$, Zahra Zamanzadeh ${ }^{5}$, Mojtaba Sohrabi ${ }^{1}$, Seyed Hesamaldin Hejazi ${ }^{6}$ \\ Received: 6 Feb 2019 \\ Published: 17 Aug 2020
}

\section{Abstract}

Background: Several studies have proven the pattern of neurotransmitters, especially serotonin, in carcinogenesis and tumor development. Several studies have also shown that changes in serotonin receptors, especially 5HTR2A and 5HTR3A, can play an important role in incidence of cancers. This study was conducted to investigate changes in mRNA expression of 5HTR2A and 5HTR3A receptors in the breast tumor tissue compared to their marginal zone.

Methods: In this study, tissue samples were obtained from 40 female patients with breast cancer. Entire RNA was obtained from the tissues and cDNA synthesis was performed. Finally, real ime PCR technique was performed to investigate the gene expression variation of both 5HTR2A and 5HTR3A. To analyze the results of real time PCR, both $\Delta \Delta \mathrm{Ct}$ and $2-\Delta \Delta \mathrm{Ct}$ equations were used. All statistical analyses were performed using the SPSS 18 software and R-Studio 1.0.136. P values less than $0.05(\mathrm{p}<0.05)$ and 0.001 $(\mathrm{p}<0.001)$ were considered statistically significant.

Results: The results showed increased expression of 5HTR2A and 5HTR3A genes in tumoral tissues of patients with breast cancer compared to their marginal tissues, where the 5HTR2A and 5HTR3A genes expression in tumor tissue was 3.12 and 3.24 times more than that of the marginal zone, respectively.

Conclusion: The results indicated an increase in the mRNA expression of serotonin receptors (5HTR2A and 5HTR3A) in the tumor tissue compared to the marginal zone, which due to the mitogenic nature of these receptors, is likely to induce more proliferation of cancer cells.

Keywords: 5HTR2A, 5HTR3A, Gene expression, Tumor, Breast cancer

Conflicts of Interest: None declared

Funding: None

*This work has been published under CC BY-NC-SA 1.0 license.

Copyright $₫$ Iran University of Medical Sciences

Cite this article as: Olfati Z, Rigi G, Vaseghi H, Zamanzadeh Z, Sohrabi M, Hejazi SH. Evaluation of serotonin receptors (5HTR2A and 5HTR3A) mRNA expression changes in tumor of breast cancer patients. Med J Islam Repub Iran. 2020 (17 Aug);34:99. https://doi.org/10.47176/mjiri.34.99

\section{Introduction}

Breast cancer is the most common cancer in women, accounting for $32 \%$ of cancers in women. According to the statistics, breast cancer is the most common type of cancer among women in Iran. (1) Several factors play a role in the incidence of breast cancer, including genetic factors,

Corresponding author: Dr Garshasb Rigi, garshasbiotech@sku.ac.ir

1. Department of Genetics, Faculty of Science, Qom Branch Islamic Azad University, Qom, Iran

2. Department of Genetics, Faculty of Basic Science, Shahrekord University, Shahrekord, Iran

3. Research Institute of Biotechnology, Shahrekord University, Shahrekord, Iran

4. Department of Photo Healing and Regeneration, Medical Laser Research Center, Yara Institute, Academic Center for Education, Culture and Research (ACECR), Tehran, Iran

5. Department of Biotechnology, Faculty of Biological Sciences and Technology, Shahid Ashrafi Esfahani University, Isfahan, Iran

6. Department of Biology, Faculty of Science, Lorestan University, Khoramabad, Iran nutrition, age at menarche, early menopause, epigenetic factors, neurological factors etc. Neurological factors are of the major factors involved in the onset of various diseases, especially cancers.

Several studies have shown the role of neurotransmitters

\section{$\uparrow$ What is "already known" in this topic:}

Previous studies have shown the role of neurotransmitters, especially 5HTR2A and 5HTR3A serotonin receptors, as mediators in the occurrence and development of cancers and their pattern in the progression of tumors and carcinogenesis.

\section{$\rightarrow$ What this article adds:}

According to the results of this study, serotonin receptor mRNA expression can be considered a prediagnosis marker for breast cancer. Also, because of its increase in tumoral tissue and considering the apoptotic effects of its antagonist on tumoral cells, it may be considered a therapeutic target for breast cancer. 
and their receptors as mediators in the occurrence and development of cancers in a variety of diseases (2-5).

Neurotransmitters are chemical messengers that used to be known as exclusive mediators between cells within the nervous system. However, in addition to the nervous system, they are believed to be involved in the immune system regulation as well (6). Many studies have shown the role of neurotransmitters, including dopamine, gamma aminobutyric acid (GABA) and particularly serotonin, in the progression of tumors and carcinogenesis (7). A study has shown that neurotransmitters, influencing through their different receptors, and changes in their mRNA expression, cause such disorders and problems in human health (7). Serotonin or 5-hydroxytryptamine (5-HT), which derived from tryptophan, is a biogenic monoamine neurotransmitter and hormone $(8,9)$. Serotonin receptors are from the G-coupled protein family, which have a 7transmembrane $\alpha$-helix structure (10). One of the serotonin receptors is 5HT2, which is widely distributed in the central nervous system (CNS) (11). 5-HT2 family consists of 5HTR2A, 5HTR2B, and 5HTR2C. They are emotional neurotransmitters that selectively bind to the protein $\mathrm{G}$ of the G11/GQ family and activate phospholipase C, which activates protein kinase $\mathrm{C}$ and releases calcium. The mRNA expression changes in this gene are involved in diseases such as schizophrenia, depression, and migraine (12-14). The 5HT3 is another serotonin receptor, and the product of this gene belongs to the ion channel receptor family, including 2 isoforms (5HTR3A and 5HTR3B) (15-17).

Various studies have shown neurotransmitter receptor agonists and antagonists can stimulate or inhibit growth in different cells $(18,19)$. Serotonin plays an important role in various diseases, such as neuropathological diseases like Parkinson's disease. For instance, serotonin agonists exacerbate the symptoms of the disease, and its antagonists have an improvement effect in this disease (20). Also, changes in the gene expression of these 2 receptors in peripheral blood mononuclear cells of people with breast cancer impair the immune system and subsequently play an important role in the disease process. Another study also showed that the specific antagonists of 5HTR3A and 5HTR2A (tropisetron and ketanserin) had an inhibitory effect on the growth and proliferation of breast cancer cells (18).

Therefore, considering the apoptotic effect of these receptors' antagonists on breast cancer cells and the lack of studies about the variation of the gene expression of these receptors in the tumoral tissue, the necessity of examining changes in the mRNA expression of these receptors in tumoral compared to their nontumoral tissues seems to be inevitable.

The aim of this study was to evaluate the serotonin receptors (5HTR2A and 5HTR3A) mRNA expression changes in tumoral tissue of breast cancer patients compared to their marginal tissue.

\section{Methods}

Sampling

The present study was conducted on 40 female breast cancer patients aged of 25-60 years through clinical and pathologic tests. Participants did not consume antidepressants and corticosteroids, did not smoke, and have not undergone chemotherapy. A tumor tissue sample and a marginal zone tissue sample were taken from all participants. They were selected from patients referring to Imam Reza and Besat hospitals in 2017-2018, and they were recruited after providing a written consent according to the ethics committee of Islamic Azad University, Qom Branch, Iran (Code of ethics committee: IR.IAU. QOM.REC.1397.016). Also, patient consent was obtained according to the Declaration of Helsinki principles.

\section{Extraction of RNA from tissue}

RNA was extracted using TRIzol ${ }^{\circ}$ (Life Sciences CO., USA). Immediately after removing from freezer at $-70^{\circ} \mathrm{C}$, the tissue was chopped with a scalpel, crushed, and powdered using liquid nitrogen in a crucible, and transferred to a 1.5 tube with a scalpel. One milliliter of TRIzol was underwent 10 seconds of vortex, 5 minutes of incubation at room temperature, and 5 minutes of centrifuge at $4^{\circ} \mathrm{C}$. The supernatant was discarded at $12000 \mathrm{~g}$. The middle layer contained RNA and was transferred to a new vial and the precipitation containing extracellular matrix, polysaccharides, and high-molecular-weight DNA was discarded. Also, $200 \mu \mathrm{L}$ of chloroform was added to the TRIzol solution containing RNA and was severely shook for 15 seconds to mix TRIzol and chloroform (Vortex can also be used.). For the next, it was placed for 2-3 minutes at $25^{\circ} \mathrm{C}$, then, centrifuged at the temperature of $4^{\circ} \mathrm{C}$ for 15 minutes at $12000 \mathrm{~g}$. Three phases became visible. The top layer was a clear aqueous phase containing RNA; the middle layer was a white cloudy phase containing DNA; and the bottom layer contained TRIzol and protein. The upper phase was carefully transferred to a new vial. Moreover, $200 \mu \mathrm{L}$ of $100 \%$ isopropanol was added to the vial. The vial was slowly turned upside down 3 times to mix the isopropanol with the aqueous phase containing RNA. It was then incubated for 20 minutes in freezer at $20^{\circ} \mathrm{C}$, then, centrifuged at $4^{\circ} \mathrm{C}$ for 10 minutes at $12000 \mathrm{~g}$. RNA precipitation is usually not visible, but sometimes a white deposit can be seen at the bottom of the vial. In either case, the supernatant was carefully disposed. One milliliter of $75 \%$ ethanol was added to the precipitation and shaken to dissolve. It was then centrifuged at $4{ }^{\circ} \mathrm{C}$ for 10 minutes at $7500 \mathrm{~g}$, then, the supernatant was carefully removed. The precipitate was stored at room temperature for 5 minutes, then, $50 \mu \mathrm{L}$ of DEPC water was added. Microtubes were placed in a hot plate for 5 minutes at $55^{\circ} \mathrm{C}$ until the precipitate was well dissolved. The solution containing the RNA was stored in a freezer at $-70^{\circ} \mathrm{C}$.

\section{Primer design}

To design primers for $\beta$-actin gene and other genes, nucleotide sequence of the genes were first obtained from the nucleic acid database (www.ncbi.nlm.nih.gov). Then, primers were designed by Oligo-7 software and reblasted online to examine their specificity against the nucleic acid database (www.ncbi.nlm.nih.gov). Also, to avoid genomic DNA amplification, at least one of primers spans an exon- 
Table 1. The sequence of primers used in this study and their specifications

\begin{tabular}{llc}
\hline Gene & \multicolumn{1}{c}{ Primer sequence } & Amplicon size \\
\hline B-actin-forward & 5'-AGACGCAGGATGGCATGGG-3' & Accession number \\
B-actin-reverse & 5'-GAGACCTTCAACACCCCAGCC-3' & NM001101.3 \\
5HT2AR -forward & 5'-AGGTATATCCATGCCAATACCAGTC-3' & NM000621.4 \\
5HT2AR -reverse & 5' -AGCTTCTTTCTGGAGTGACTTGAT-3' & NMp \\
5HT3AR-forward & 5'-GCACACCATCCAGGACATCAAC-3' & NM213621.3 \\
5HT3AR- reverse & 5'-GACCCTCTCGCCACTGTTGG-3' & \\
\hline
\end{tabular}

exon junction.

\section{RT-PCR}

Firstly, according to the existing concentrations of each RNA sample reported by the NanoDrop device, similar concentrations of the samples were prepared using the water present in the kit or DEPC water.

To synchronize all extracted RNA samples, the RNA concentrations were determined using by NanoDrop equipment. To synthesize the first-strand cDNA, 1 microliter of any extracted RNA sample was applied using the cDNA synthesis kit (Fermentas, Thermo Fisher Scientific, Germany). The cDNA synthesis was also performed according to the manual of the company. The primers were peeked applying the Oligo7 software (www.oligo.net) for the 5HTR3A, 5HTR2A, and $\beta$-actin (as housekeeping) genes, according to the sequences submitted in the GenBank. The specificity and accuracy of these genes and the related nucleotides were investigated applying the BLAST online alignment software from the NCBI database (http://blast.ncbi.nlm.nih.gov/Blast.cgi) (Table 1).

To investigate the expression of the related mRNA of the 5HTR3A and 5HTR2A genes, the PCR technique was conducted for all tubes in a final volume of $20 \mu \mathrm{L}$ with 1 Unit of Taq DNA polymerase (CinnaGen, Iran). Reaction component included $2-2.5 \mathrm{mM} \mathrm{MgCl} 2,0.5 \mathrm{mM}$ each of the dNTPs, $0.8-1 \mathrm{pM}$ primers, $2.5 \mu \mathrm{L}$ Taq DNA polymerase (Sinagene, Iran), and for each RT-PCR reaction, $1 \mu \mathrm{L}$ of the synthetized cDNA was applied as a template.

For 5HTR3A, 5HTR2A, and b-actin genes amplification, the initiation stage of the PCR program was at $95^{\circ} \mathrm{C}$ for 5 minutes and amplification was performed during 35 cycles at $95^{\circ} \mathrm{C}$ for 50 seconds, $62^{\circ} \mathrm{C}$ for $5 \mathrm{HTR} 3 \mathrm{~A}$ and 5HTR2A and beta actin genes for 40 seconds (annealing step) and $72^{\circ} \mathrm{C}$ for 1 minute (extension step), followed by a final extension step at $72^{\circ} \mathrm{C}$ for 10 minutes. Finally, the PCR products were visualized using the gel electrophoresis on a $2 \%$ agarose gel. To correctly confirm the primers, a positive control was applied.

\section{qRT-PCR (real-time PCR)}

A green master mix with fluorescence dye (SYBER GREEN Genaxxon kit, Germany) was applied to detect the cDNA amplification for performing and confirming the real time PCR, which is performed by monitoring, detecting, and computing the increase in fluorescence severity and applying the specific primer pairs for 5HT2AR -forward, 5HT2AR -reverse (transcript I), 5HT3ARforward, 5HT3AR- reverse (transcript II), and $\beta$-actin (internal control) in a real time PCR instrument manufactured by Bio Molecular Systems (BMS), Australia, based on the manufacturer's instructions (21).

\section{Statistical analysis of $q R T-P C R$ results}

To analyze the results of real time PCR, both $\Delta \Delta \mathrm{Ct}$ and $2^{-\Delta \Delta C t}$ equations were used. The alteration of fold change was defined using $2^{-\Delta \Delta \mathrm{Ct}}$ and the changes in the gene expression levels were determined through $\Delta \Delta \mathrm{Ct}(14,21)$. Because all types of tissue samples containing tumor, correspond, and contra lateral breast samples were taken from 1 person, the respective variation of various 5HTR3A and 5HTR2A gene expression in the tissue samples were evaluated compared to the $\beta$-actin using the paired-samples $t$ test. The correlation between the changes in mRNA expression rate of 5HTR3A and 5HTR2A and other quantitative, qualitative, and clinicopathologic elements of the patients were determined. The Spearman and Pearson tests were applied to analyze the correlation of each mRNA level. One-way ANOVA test was performed to evaluate the changes of the various receptors in several steps, the pathological grade, and the lymphatic invasion condition releasing between 3 or more groups.

All analyses were performed applying the SPSS 18 software and R-Studio 1.0.136. In this project, $\mathrm{p}$ values less than $0.05(p<0.05)$ were considered statistically significant.

\section{Results}

5HTR2A and 5HTR3A serotonin receptor expression evaluation by $R T-P C R$

After extraction of RNA and synthesis of cDNA, 5HTR2A and 5HTR3A receptors expression was evaluated using specific primers for these genes for tumor and healthy samples. The results of RT-PCR showed the 5HTR2A and 5HTR3A receptors investigated in this study were expressed in in tumor tissue of breast cancer patients (Fig. 1).

\section{HTR2A and 5HTR3A serotonin receptor quantitative} expression evaluation by $q R T-P C R$

The results obtained from of real time PCR done using $\triangle \triangle \mathrm{CT}$ method indicated increased expression of 5HTR2A and 5HTR3A genes in tumoral tissues of patients with breast cancer compared to their marginal tissues, where the 5HTR2A and 5HTR3A genes expression in tumor tissue was 3.12 and 3.24 times more than that of the marginal zone, respectively (Table 2).

Gene expression level, which represents the distribution of real time PCR data also showed the increase in both 5HTR3A and 5HTR2A gene expression (Fig. 2). 


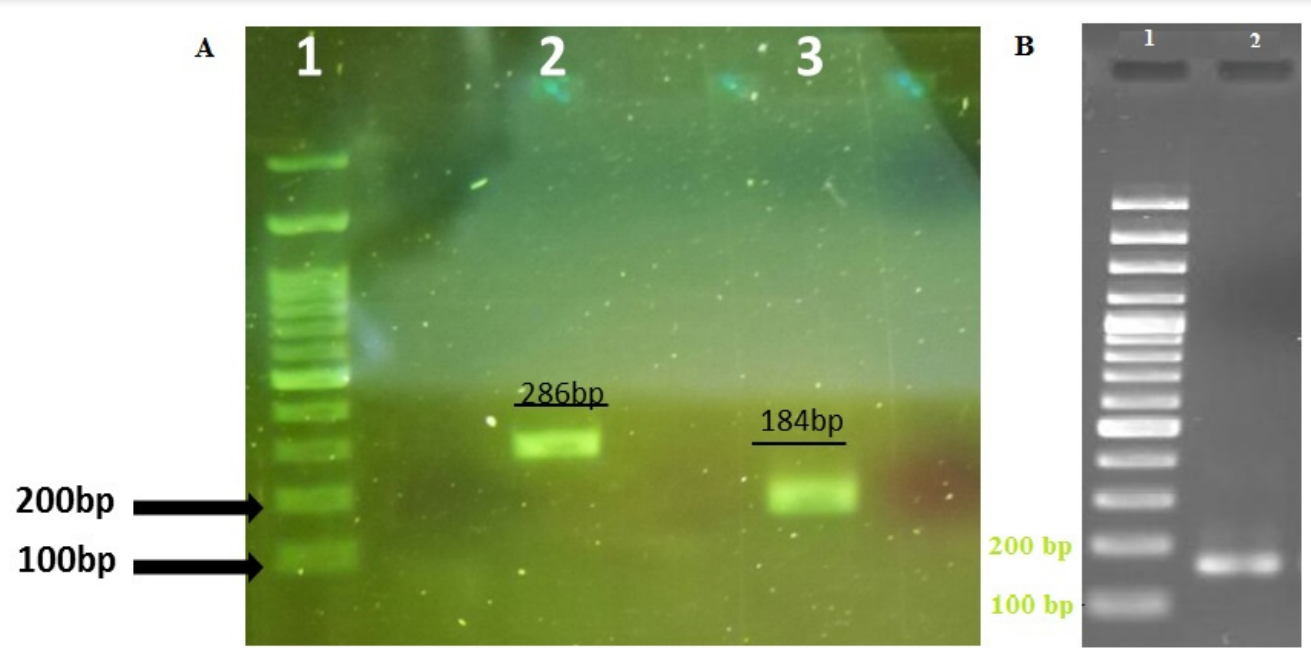

Fig. 1. A) The bands associated with serotonin receptors 5HTR2A and 5HTR3A on gel electrophoresis: Well 1: Size marker 100 bp (Fermentas, USA), Well 2: 5HTR3A gene product expression in tumor tissue of breast cancer patients, Well 3: 5HTR2A gene product expression in tumor tissue of breast cancer patients. B) The bands associated with beta- actin mRNA expression on gel electrophoresis as a positive control: Well 1: Size marker 100 bp (Fermentas, USA), Well 2: B- actin gene product expression in tumor tissue of breast cancer patients.

Table 2. The results of the changes in the expression of the studied genes obtained by $\Delta \Delta \mathrm{CT}$ analysis

\begin{tabular}{lcccc}
\hline Gene & Ratio $(\times$ fold $)$ & Standard error & P-value & Gene expression \\
\hline 5HTR2A & $3 / 12$ & \pm 0.51 & $<0.001$ & UP \\
5HTR3A & $3 / 24$ & \pm 0.82 & 0.047 & UP \\
\hline
\end{tabular}
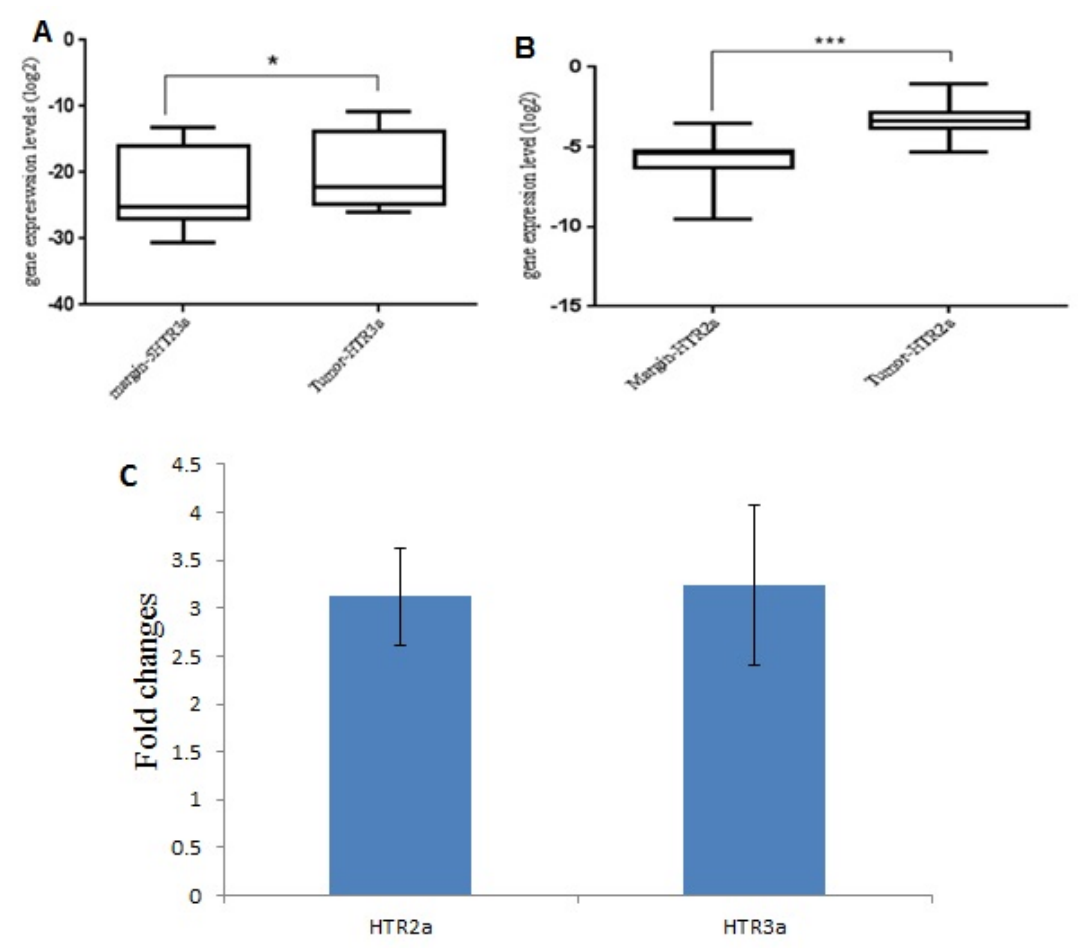

Fig. 2. 5HTR3A and 5HTR2A gene expression level changes in tumor samples compared to the marginal zone.

A) 5HTR3A gene expression in the tumor tissues and marginal zone; B) 5HTR2A gene expression in the tumor tissues and marginal zone; C) 5HTR3A and 5HTR2A gene expression in the tumor tissues and marginal zone based on fold changes.

*: Significance level $\mathrm{p}<0.05,{ }^{* * *}$ : Significant level $\mathrm{P}<0.001$

\section{Pathologic analysis}

Pathological studies were reported in our previous study (22), and in these 2 studies the tumor and healthy samples were obtained from the same participants; the information regarding pathological characteristics are shown in Tables 3 and 4 . The correlation and dependency between these information, containing pregnancy, lactation, menstruation, breastfeeding, and abortion (Table 3) were evaluated, 


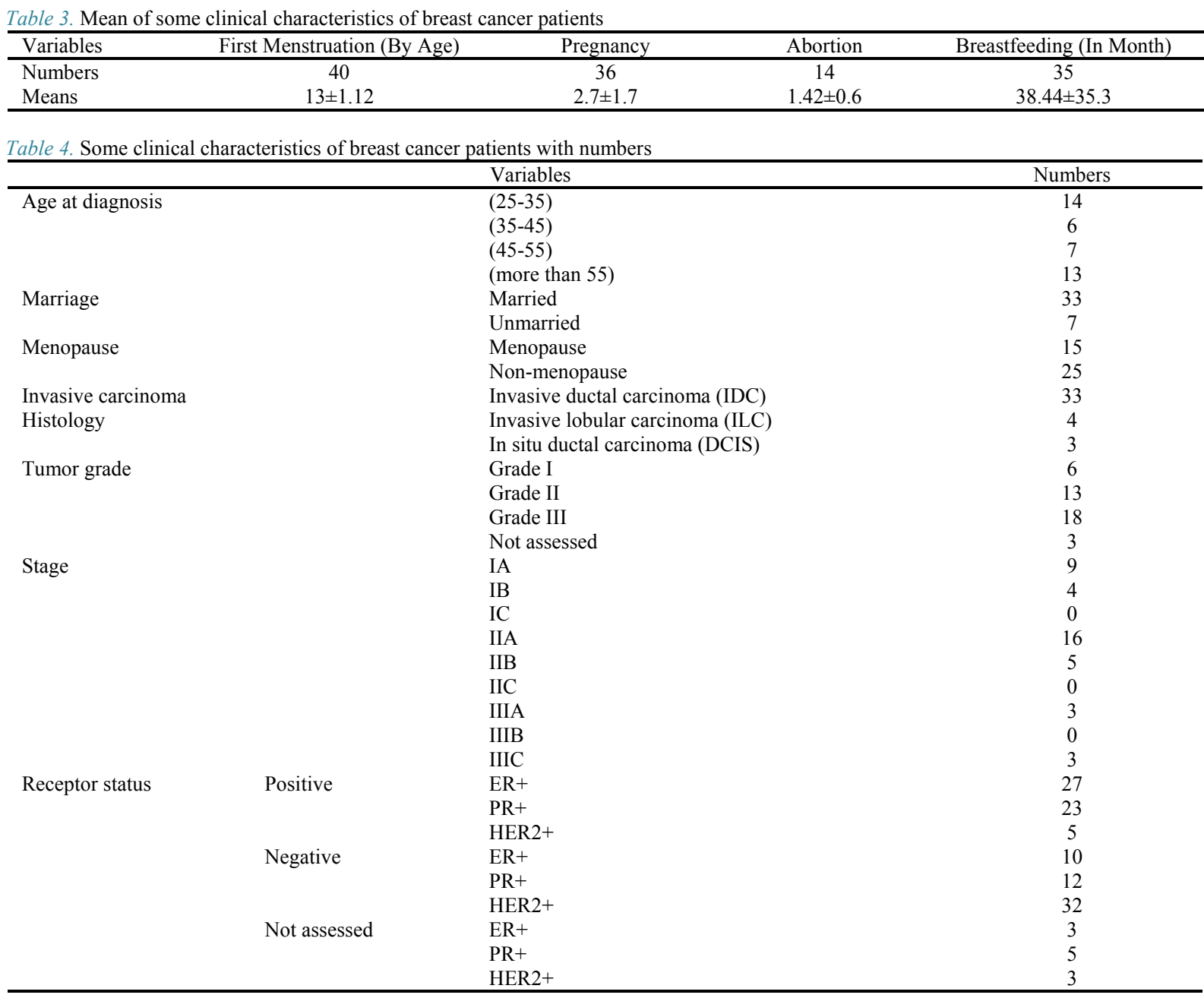

and their dependency with 5HTR3A and 5HTR2A gene expression was recognized. Also, some other demographic data related to the patients, including age, invasion to lymph nodes status, and their marital status, are shown in Table 4.

\section{Statistical analyses}

Clinical data continuity analysis also showed 5HTR2A and 5HTR3A gene expression level was significantly correlated with patients with a history of surgery (Cor= $0.437, \mathrm{P}=0.037, \mathrm{~N}=40$ ).

Lymph nodes invasion was also observed in people with increased 5HTR2A gene expression (Cancer cells were found in their lymph nodes.) (Cor $=0.53, \mathrm{P}=0.015, \mathrm{~N}=$ $30)$. Also, the number of pregnancies was directly correlated with miscarriage (Cor $=0.501, \mathrm{P}=0.015, \mathrm{~N}=33$ ). Studies show abortion has a significant relationship with family history $(\mathrm{Cor}=0.426, \mathrm{P}=0.048, \mathrm{~N}=40$ ). The results of the study showed age has a significant relationship with pregnancy $(\mathrm{Cor}=0.449, \mathrm{P}=0.032, \mathrm{~N}=40)$.

\section{Sequencing}

The results of the sequencing confirmed the accuracy of the specific amplification of the genes examined in this study.

\section{Discussion}

According to the preliminary hypothesis, the results of this study were aimed at increased mRNA expression of serotonin receptors (5HTR2A and 5HTR3A) in the breast tumor tissue compared to the normal marginal zone. This could be due to the oncogenic role of these receptors in breast cancer and interference in the signaling pathways resulting in the induction of cell proliferation in cancerous cells. In previous studies, the mitogenic role of serotonin in prostate cancer has been revealed $(22,23)$. According to past results, the relationship between neurotransmitters, including serotonin, and breast cancer plays an important role in the development of tumor cells (24).

Soll et al (2010) evaluated the role of serotonin in liver cancer and found serotonin stimulates the growth of tumor cells in liver cancer (25).

Siddiqui EJ et al (2005) found serotonin is a growth factor in a variety of cancerous and noncancerous cells. In their study, serotonin was introduced as a tumor growth stimulator in a variety of cancers, including colon, lung, and prostate cancers. On the other hand, serotonin antagonists have been identified as growth-inhibiting agents in cancer cells, and these antagonists have been suggested as a proposed cancer treatment (26). In another study on the relationship between serotonin and bladder cancer, Siddiqui EJ et al found serotonin antagonists significantly 
inhibit cell proliferation in bladder cancer with a high grade. These antagonists exert their effects through serotonin receptors (27). Another study on the effect of serotonin antagonists in prostate cancer found serotonin antagonists, in addition to inhibiting the growth of cancer cells, induce apoptosis in these cells (28).

A study by Atayi et al (2010) showed tumor receptors in colon cancer had increased mRNA expression in comparison to the normal cells (29). This indicates the association between increased serotonin receptors and colon cancer. Other studies discovered that serotonin receptors induce angiogenesis in lung cancer $(24,30)$.

Dizeyi et al (2004) examined the role of serotonin receptors and their antagonists in prostate cancer. Their results illustrated that serotonin receptors had an increased mRNA expression in high-grade malignant tumors. On the other hand, serotonin receptor antagonists inhibit proliferation in prostate cancer cells (31).

In a study by Hejazy et al (2015), 5HTR2A and 5HTR3A antagonists could lead to the apoptosis of human breast cancer cells (MCF-7), and had an inhibitory effect on the proliferation of these cells. Their study showed the mitogenic role of serotonin receptors (18).

In the present study, mRNA expression of 5HTR2A and 5HTR3A serotonin receptors significantly increased in the tumor tissues by 3.12 and 3.24 times, respectively, compared to healthy tissues surrounding the tumor.

Therefore, considering the mitogenic effects of these receptors, and due to the increased mRNA expression of 5HTR2A and 5HTR3A in tumor tissue in breast cancer patients, the mRNA expression of these receptors may be associated with the pathogenicity of cancer.

In this study, individuals with increased 5HTR2A gene expression also had an invasion of lymph nodes. This indicates the association between increased mRNA expression of this receptor and the increased risk of cancer cells invading the lymph tissue in these patients.

Based on the above-mentioned studies, it can be concluded that by inhibiting serotonin receptors, the angiogenesis of cancer cells decreases and the growth of tumor masses diminishes. However, in some studies on liver cancer, reducing the mRNA expression of serotonin receptors increased the proliferation of cancer cells, which may be due to different cell models and the nature of the cells used (32). Another study also showed that high levels of serotonin can induce the growth of cancer cells in lung cancer in experimental mice, and, on the other hand, lower serotonin levels reduce the growth of tumor cells in lung cancer in mice models (33). This suggests serotonin functions in accordance to its concentration in some cancers.

\section{Conclusion}

Hence, based on the proliferative effects of these receptors on breast cancer cells, and considering the increase of these receptors in tumoral tissue, these arising can be effective in development of breast cancer. Although some complimentary studies are needed to approve the claim, according to the results of this study and those of previous studies, serotonin receptor mRNA expression can be con- sidered a prediagnosis marker for breast cancer. Also, because of their increase in tumoral tissue, and considering the apoptotic effects of their antagonist on tumoral cells, serotonin receptor mRNA expressions may be considered a therapeutic target for breast cancer in future studies.

\section{Acknowledgments}

This study was performed to implement Zahra Olfati Master's thesis at Department of Genetics, Faculty of Science, Qom Branch, Islamic Azad University, Qom, Iran. The authors would like to thank the Research Institute of Biotechnology, Shahrekord University, Shahrekord, Iran, for providing the necessary equipment.

\section{Ethical conduct of research}

The authors state that they have obtained appropriate institutional review board approval or have followed the principles outlined in the Declaration of Helsinki for all human or animal experimental investigations. In addition, for investigations involving human subjects, informed consent was obtained from the participants involved.

\section{Conflict of Interests}

The authors declare that they have no competing interests.

\section{References}

1. Akbari A, Razzaghi Z, Homaee F, Khayamzadeh M, Movahedi M, Akbari ME. Parity and breastfeeding are preventive measures against breast cancer in Iranian women. Breast Cancer. 2011;18(1):51-5.

2. Pornour M, Ahangari G, Hejazi SH, Ahmadkhaniha HR, Akbari ME. Dopamine receptor gene (DRD1-DRD5) expression changes as stress factors associated with breast cancer. Asian Pac J Cancer Prev. 2014;15(23):10339-43

3. Gurbuz N, Ashour AA, Alpay SN, Ozpolat B. Down-regulation of 5HT1B and- ${ }^{\circ}$ HT1D receptors inhibits proliferation, clonogenicity and invasion of human pancreatic cancer cells. Plos One. 2014;9(8):e105245.

4. Vaseghi H, Pornour M, Djavid GE, Rigi G, Ganji SM, Novin L. Association of the gene expression variation of tumor necrosis factoralpha and expressions changes of dopamine receptor genes in progression of diabetic severe foot ulcers. Iran J Basic Med Sci. 2017;20(11):1213-9.

5. Ebrahimzadeh N, Vaseghi H, Rigi G, Esmaeeli Djavid G, Mohammad Ganji S, Farhoud A, et al. DRD2 Dopamine Receptor and IL-1 $\beta$ Gene Expression Changes Involved in Wound Healing in Type 2 Diabetic Patients with Foot Ulcer. Int J Med Sci. 2018;28(162):47-58.

6. Reiche EM, Nunes SO, Morimoto HK. Stress, depression, the immune system, and cancer. Lancet Oncol. 2004;5(10):617-25.

7. Jobling P, Pundavela J, Oliveira SM, Roselli S, Walker MM, Hondermarck H. Nerve-Cancer Cell Cross-talk: A Novel Promoter of Tumor Progression. Cancer Res. 2018;15(9):75-81..

8. Kagami S, Saeki H, Idezuki T, Yano S, Kawabata Y, Okochi H, et al. Epithelioid sarcoma associated with lung adenocarcinoma. J Dermatol. 2005;32(11):904-8.

9. Siegel RL, Miller KD, Jemal A. Cancer statistics, 2016. CA Cancer J Clin. 2016;66(1):7-30.

10. McCorvy JD, Roth BL. Structure and function of serotonin G protein-coupled receptors. Pharmacol Ther. 2015;150:129-42.

11. Storer RI, Brennan PE, Brown AD, Bungay PJ, Conlon KM, Corbett MS, et al. Multiparameter optimization in CNS drug discovery: Design of Pyrimido [4, 5-d] azepines as potent 5-Hydroxytryptamine 2C (5HT2C) receptor agonists with exquisite functional selectivity over 5HT2A and 5-HT2B receptors. J Med Chem. 2014;57(12):5258-69.

12. Ghiringhelli F, Apetoh L. Chemotherapy and immunomodulation: from immunogenic chemotherapies to novel therapeutic strategies. Future Oncol. 2013;9(4):469-72. 
13. Roth BL, Willins DL, Kristiansen K, Kroeze WK. 5Hydroxytryptamine2-family receptors (5-hydroxytryptamine2A, 5hydroxytryptamine2B, 5-hydroxytryptamine2C): where structure meets function. Pharmacol Ther. 1998;79(3):231-57.

14. Hejazi SH, Ahangari G, Pornour M, Deezagi A, Aminzadeh S, Ahmadkhaniha HR, et al. Evaluation of gene expression changes of serotonin receptors, 5-HT3AR and 5-HT2AR as main stress factors in breast cancer patients. Asian Pac J Cancer Prev. 2014;15(11):4455-8.

15. Blanc E, Wagner P, Plaisier F, Schmitt M, Durroux T, Bourguignon $\mathrm{JJ}$, et al. Design and validation of a homogeneous time-resolved fluorescence cell-based assay targeting the ligand-gated ion channel 5HT3A. Anal Biochem. 2015;484:105-12.

16. Di Maio D, Chandramouli B, Brancato G. Pathways and barriers for ion translocation through the 5-HT3A receptor channel. PloS One. 2015;10(10):e0140258.

17. Lochner M, Lummis SC. Agonists and antagonists bind to an A-A interface in the heteromeric 5-HT3AB receptor. Biophys J. 2010;98(8):1495-1502.

18. Hejazi SH, Ahangari G, Deezagi A. Alternative viewpoint against breast cancer Based on selective serotonin seceptors 5HTR3A and 5HTR2A antagonists that can mediate apoptosis in MCF-7 cell line. Curr Drug Deliv. 2015;12(4):240-249.

19. Pornour M, Ahangari G, Hejazi SH, Deezagi A. New perspective therapy of breast cancer based on selective dopamine receptor D2 agonist and antagonist effects on MCF-7 cell line. Recent Pat Anticancer Drug Discov. 2015;10(2):214-23.

20. Karila D, Freret T, Bouet V, Boulouard M, Dallemagne P, Rochais C. Therapeutic Potential of 5-HT6 Receptor Agonists: Miniperspective. J Med Chem. 2015;58(20):7901-12.

21. Ariana M, Arabi N, Pornour M, Vaseghi H, Ganji SM, Alivand MR, et al. The diversity in the expression profile of caveolin II transcripts, considering its new transcript in breast cancer. J Cell Biochem. 2018;119(2):2168-78.

22. Ariana M, Pornour M, Mehr SS, Vaseghi H, Ganji SM, Alivand MR, et al Preventive effects of oxytocin and oxytocin receptor in breast cancer pathogenesis. Per Med. 2019;16(1):25-34.

23. Sarrouilhe D, Clarhaut J, Defamie N, Mesnil M. Serotonin and cancer: what is the link? Curr Mol Med. 2015;15(1):62-77.

24. Banskota S, Gautam J, Regmi SC, Gurung P, Park M-H, Kim SJ, et al. BJ-1108, a 6-Amino-2, 4, 5-Trimethylpyridin-3-ol analog, inhibits serotonin-induced angiogenesis and tumor growth through PI3K/NOX Pathway. PLoS One. 2016;11(1):e0148133.

25. Soll C, Jang JH, Riener MO, Moritz W, Wild PJ, Graf R, et al. Serotonin promotes tumor growth in human hepatocellular cancer. Hepatology. 2010;51(4):1244-54.

26. Siddiqui EJ, Thompson CS, Mikhailidis DP, Mumtaz FH. The role of serotonin in tumour growth (review). Oncol Rep. 2005;14(6):1593-7.

27. Siddiqui EJ, Shabbir MA, Mikhailidis DP, Mumtaz FH, Thompson CS. The effect of serotonin and serotonin antagonists on bladder cancer cell proliferation. BJU Int. 2006;97(3):634-9.

28. Siddiqui EJ ,Shabbir M, Mikhailidis DP, Thompson CS, Mumtaz FH. The role of serotonin (5-hydroxytryptamine1A and 1B) receptors in prostate cancer cell proliferation. J Urol. 2006;176(4):1648-53.

29. Ataee R, Ajdary S, Zarrindast M, Rezayat M, Hayatbakhsh MR. Anti-mitogenic and apoptotic effects of 5-HT1B receptor antagonist on HT29 colorectal cancer cell line. J Cancer Res Clin Oncol. 2010;136(10):1461-9.

30. Asada M, Ebihara S, Yamanda S, Niu K, Okazaki T, Sora I, et al. Depletion of serotonin and selective inhibition of $2 \mathrm{~B}$ receptor suppressed tumor angiogenesis by inhibiting endothelial nitric oxide synthase and extracellular signal-regulated kinase $1 / 2$ phosphorylation. Neoplasia. 2009;11(4):408-417.

31. Dizeyi N, Bjartell A, Nilsson E, Hansson J, Gadaleanu V, Cross N, et al. Expression of serotonin receptors and role of serotonin in human prostate cancer tissue and cell lines. Prostate. 2004;59(3):328-36.

32. Sulaiman P, Joseph B, Kaimal SB, Paulose CS. Decreased hepatic 5HT $1 \mathrm{~A}$ receptors during liver regeneration and neoplasia in rats. Neurochem Res. 2008;33(3):444-9.

33. Vicaut E, Laemmel E, Stücker O. Impact of serotonin on tumour growth. Ann Med. 2000;32(3):187-94. 